\title{
Dynamics of Microbial Communities in an Earthen Shrimp Pond during the Shrimp Growing Period
}

\author{
Siriphorn Sombatjinda (Corresponding author) \\ School of Bioresources and Technology, King Mongkut's University of Technology Thonburi \\ Bangkhuntien, Bangkok 10150, Thailand \\ E-mail: sombatjinda@hotmail.com
}

Nimaradee Boonapatcharoen

Excellent Center of Waste Utilization and Management, Pilot Plant Development and Training Institute

King Mongkut's University of Technology Thonburi, Bangkhuntien, Bangkok 10150, Thailand

Marasri Ruengjitchatchawalya

School of Bioresources and Technology, King Mongkut's University of Technology Thonburi

Bangkhuntien, Bangkok 10150, Thailand

Chalermraj Wantawin

Department of Environmental Engineering, King Mongkut's University of Technology Thonburi

Thungkru, Bangkok 10140, Thailand

Boonsirm Withyachumnarnkul

Center of Excellence for Shrimp Molecular Biology and Biotechnology

Faculty of Science, Mahidol University, Ratchathewi, Bangkok 10400, Thailand

Somkiet Techkarnjanaruk

Excellent Center of Waste Utilization and Management

National Center of Genetic Engineering and Biotechnology, King Mongkut's University of Technology Thonburi Bangkhuntien, Bangkok 10150, Thailand

Received: August 17, 2011

Accepted: October 30, $2011 \quad$ Published: December 1, 2011

doi:10.5539/enrr.v1n1p171

URL: http://dx.doi.org/10.5539/enrr.v1n1p171

\begin{abstract}
Correlations between the activities of microbial communities and water quality in an earthen pond were investigated monthly during the shrimp growing period. The TAN gradually decreased compared to the beginning time, thereby resulting in an overall decrease of $81.3 \%$. In contrast, the overall nitrate concentration increased $46.3 \%$ over this same period. Microbial community analysis using PCR-DGGE showed that changes in community dynamics that occurred during the shrimp growing period might be correlated to water quality. Overall, there were 3 groups of microbial dynamics. The $1^{\text {st }}$ was observed in all investigations, was microflora found in the shrimp culturing system, which included the following: Nitrosomonas eutropha, Exiguobacterium SKRP 5, and Exiguobacteria sp. CNJ771. The $2^{\text {nd }}$ involved the replacement of bacteria from one type to another, such as from Flavobacteriales bacterium to Aquiflexum balticum, which are involved in shrimp shell degradation. The $3^{\text {rd }}$ consisted of microbes observed at only one time point, such as Synechococcus sp. Y0011 $\left(\mathrm{W}_{0}\right)$, and Stenotrophomonas maltophilia $\left(\mathrm{W}_{3}\right)$, or at several time points, such as Pseudomonas lanceolata $\left(\mathrm{W}_{0}\right.$ and $\left.\mathrm{W}_{3}\right)$
\end{abstract}


and Burkholderia sp. WBF2 $\left(\mathrm{W}_{1}\right.$ and $\left.\mathrm{W}_{2}\right)$. Although this third group of bacteria was not found at all time points tested, the group was important for balancing the shrimp culturing system, which is important for a successful shrimp cultivation.

Keywords: Microbial community, DGGE, 16S rRNA genes, Shrimp farming water

\section{Introduction}

In spite of many challenges, Thailand has retained global dominance in shrimp production for over a decade, providing a major source of income, foreign exchange generation, and livelihood opportunities (Pouliotte, Islam, Smit, \& Islam, 2006). Thai shrimp farming essentially consists of small-scale, owner-managed and owner-operated practices (Kongkeo \& Davy). The requirements for successful shrimp farming are the maintenance of water quality and of the balance between beneficial and pathogenic bacteria. Between 1994 and 1997, shrimp production in Thailand dropped by $40 \%$, due to disease caused by bacterial pathogens and shrimp viruses (Moriarty, 1999); a high density of shrimp is conducive for the spread of pathogens. The solution lies in the field of microbial ecology, not in the field of pharmacology, i.e., in the development of new antibiotics or vaccines (Kesarcodi-Watson, Kaspar, Lategan, \& Gibson, 2008). Using beneficial bacteria (probiotics) to displace pathogenic bacteria by competitive processes is a more efficient remedy than administering antibiotics. Also, many commercial shrimp ponds were operating with daily water exchange rates of $10-15 \%$ to maintain water quality. Water exchange rates were identified as an important factor contributing to several disease in shrimp growing areas. Therefore, water quality control and microbial community balance are necessary for successful shrimp cultivations (Sandifer \& Hopkins, 1996).

Data regarding the abundance and phylogenetic relationship of microorganisms based on 16S rRNA gene-targeting techniques, such as denaturing gradient gel electrophoresis (DGGE), are suitable cultivation-independent tools for the analysis of complex microbial communities (Amann, Ludwig, \& Schleifer, 1995). In order to gain insight into the correlation between microbial communities and water quality, microbial communities and their dynamics and activities in shrimp farming water were analyzed by comparative sequence analysis of the 16S rRNA genes, which were amplified from total genomic DNA derived from the microbial community.

\section{Materials and Methods}

\subsection{Shrimp farming water samples}

Shrimp farming water samples were collected from a semi-intensive shrimp culture pond of white shrimps (Penaeus vannamei) located in Thung-Kru district, Bangkok, Thailand. A total of 4 water samples were studied in this report. $\mathrm{W}_{0}$ represented water samples taken before shrimp were released into the earthen pond. $\mathrm{W}_{1}, \mathrm{~W}_{2}$ and $\mathrm{W}_{3}$ represented water samples taken one, two and three months, respectively, after the shrimp were released. Sample collection, stabilization, and transportation to the laboratory as well as sample storage were done according to the Standard Methods of Strickland and Parsons (Strickland \& Parsons, 1972).

\subsection{Analysis of water quality}

Water samples were taken from the shrimp pond at 3 different depths: 10,50 and $80 \mathrm{~cm}$. Levels of total ammonia nitrogen (TAN, including $\mathrm{NH}_{3}{ }^{+}$and $\mathrm{NH}_{4}{ }^{+}$), nitrate, nitrite, phosphate, chlorophyll $a$ and temperature and salinity were determined as previously described (Strickland \& Parsons, 1972).

\subsection{Total Genomic DNA Extraction}

For each time point and water depth, seven liters of shrimp water were successively filtered through 0.45 - and $0.2-\mu \mathrm{m}$ filters. The filtrates were resuspended in $10 \mathrm{ml}$ of $1 \mathrm{X}$ phosphate buffer solution (PBS) and frozen at -20 ${ }^{\circ} \mathrm{C}$. Total genomic DNA was extracted using a method modified from Zhou et al. (Zhou, Bruns, \& Tiedje, 1996). For each sample, a 5-ml suspension (mixture of PBS and filtrate) was centrifuged at 14,000 rpm for $5 \mathrm{~min}$. Cell pellets were collected and resuspended in $300 \mu \mathrm{l}$ of lysozyme solution containing $10 \mathrm{mg} / \mathrm{ml}$ lysozyme, $0.15 \mathrm{M}$ $\mathrm{NaCl}$, and $0.1 \mathrm{M} \mathrm{Na}_{2} \mathrm{EDTA}, \mathrm{pH}$ 8.0. The resuspended samples were incubated at $37{ }^{\circ} \mathrm{C}$ for $1 \mathrm{~h}$ and mixed by inversion every $15 \mathrm{~min}$. After cooling on ice, $300 \mu \mathrm{l}$ of SDS buffer $(0.5 \mathrm{M}$ Tris- $\mathrm{HCl}, 0.1 \mathrm{M} \mathrm{NaCl}, \mathrm{pH} 8.0,4 \%$ sodium dodecyl sulfate) was added to each of the samples. The samples were incubated for $10 \mathrm{~min}$ and were placed at $55{ }^{\circ} \mathrm{C}$ for $10 \mathrm{~min}$. Next, the genomic DNA was extracted and purified from the lysates by three sequential phenol-chloroform extractions followed by precipitation with isopropanol (Sambrook, Fritsch, \& Maniatis, 1989). The DNA pellets were washed with $70 \%$ ethanol resuspended in sterile TE buffer (50 mM Tris- $\mathrm{HCl}, 1 \mathrm{mM} \mathrm{Na}{ }_{2} \mathrm{EDTA}, \mathrm{pH} 8.0$ ) and stored at $-20^{\circ} \mathrm{C}$. 


\subsection{Nested PCR amplification}

PCR amplification was performed with a Biometra Thermal Cycler (Biometra, Gottingen, Germany). For full-length $16 \mathrm{~S}$ rDNA amplification, the gene fragment from the variable bacterial V3 region was amplified using the forward primer EUB 8F (5'- GAG TTT GAT CCT GGC TCA G -3') and the universal reverse primer U1492R (5'- GGT TAC CTT GTT ACG ACT T -3'). Reaction mixtures (50 $\mu \mathrm{L})$ contained $5 \mu \mathrm{L}$ of 10X PCR buffer, $1 \mu \mathrm{L}$ dNTPs $(25 \mathrm{mM}), 3 \mu \mathrm{L} \mathrm{MgCl}_{2}(25 \mathrm{mM}), 0.25 \mu \mathrm{L}$ Taq polymerase $(250 \mathrm{U}), 1 \mu \mathrm{L}$ DNA template (50-200 ng), and $0.5 \mu \mathrm{L}$ of each primer (20 ng each). The reaction cycling parameters included an initial denaturation step of $5 \mathrm{~min}$ at $95{ }^{\circ} \mathrm{C}$ followed by 30 cycles of denaturation for $30 \mathrm{~s}$ at $94{ }^{\circ} \mathrm{C}$, annealing for $30 \mathrm{~s}$ at $55^{\circ} \mathrm{C}$ and elongation for $30 \mathrm{~s}$ at $72{ }^{\circ} \mathrm{C}$ with a final extension step of $5 \mathrm{~min}$ at $72{ }^{\circ} \mathrm{C}$ (Watts, Wu, Schreier, May, \& Sowers, 2001). PCR products were checked for size and yield on a $0.8 \%(\mathrm{w} / \mathrm{v})$ agarose gel in TAE buffer (20 $\mathrm{mM}$ Tris- $\mathrm{HCl}, 10 \mathrm{mM}$ sodium acetate, $0.5 \mathrm{mM} \mathrm{Na} \mathrm{N}_{2} \mathrm{EDTA}, \mathrm{pH}$ 8.0). For nested PCR, $1 \mu \mathrm{L}$ of full length of $16 \mathrm{~S}$ rDNA was used as a template with primers 338GC-f and 518R (sequences provided in the following section) (Devereux, Kane, Winfrey, \& Stahl, 1992) at an annealing temperature of $58{ }^{\circ} \mathrm{C}$.

\subsection{DGGE analysis}

The product obtained from the nested PCR amplification was used as template DNA in the second PCR with the bacterial DGGers 338GC-F (5'-CGCCCGCCGCGCGCGGCGGGCGGGGCGGGGGCACGGGGGGACTCCTACGGGAGGCA-3') and 518R (5'-ATTACCGCGGC TGCTGG-3'), which target the V2 to V3 region (Devereux, et al., 1992). DGGE analysis of the PCR products was performed using the DGGE-2000 apparatus (CBS Scientific Company, CA), according to the manufacturer's instructions. The program for amplification was as described above but with an annealing temperature at $58{ }^{\circ} \mathrm{C}$ (Dar, Kuenen, \& Muyzer, 2005). Samples were loaded on a $6.5 \%$ polyacrylamide gel in $0.5 \times \mathrm{TAE}$ buffer. An optimal separation of bands was achieved using a parallel and linear denaturing gradient ranging from 40 to $55 \%$ denaturing solution ( $7 \mathrm{M}$ urea and $40 \%$ formamide) and run for 5 hours at $200 \mathrm{~V}$ with a constant temperature of $60^{\circ} \mathrm{C}$. The DGGE gels were stained with SYBR ${ }^{\circledR}$ Gold (Invitrogen, Belgium) for $20 \mathrm{~min}$ at room temperature and photographed under a UV transilluminator.

\subsection{Phylogenetic analysis}

Similarity searches for 16S rRNA gene sequences were accomplished using the NCBI BLAST search program within GenBank databases (http://blast.ncbi.nlm.nih.gov/Blast/) (Altschul, et al., 1997). Phylogenetic analysis was performed using the Ribosomal Database Project Version 9 program (http://rdp.cme.msu.edu/) with default settings for various algorithms. Phylogenetic relationships were inferred by a distance matrix. Nucleotide sequences obtained in this study have been deposited in GenBank under accession numbers HQ433553 HQ433573.

\section{Results and Discussion}

\subsection{Water quality during shrimp cultivation period}

During the shrimp growing period (90-day the period it takes a juvenile to reach maturity or "market size"), water quality, including physical and chemical properties, was determined; the results are shown in Table 1 . The $\mathrm{pH}$ was consistently between 7.8-8.0, which has been previously described as the optimal range for shrimp cultivation (Cook \& Murphy, 1969). However, the temperature fluctuated over the course of sampling, due to seasonal changes. The lowest temperature was $18.2{ }^{\circ} \mathrm{C}$ in winter, and the highest temperature was $28.6{ }^{\circ} \mathrm{C}$ in early summer. Salinity decreased over the course of the shrimp growing period, due to the cultivation strategy implemented at this pond. Low-salinity conditions for shrimp has been preferable for overcoming problems of diseases from luminescent bacteria or toxic dinoflagellate plankton (Limsuwan, Somsiri, \& Silarudee, 2002). Total ammonia nitrogen (TAN) concentrations decreased slightly from $0.262 \pm 0.014$ to $0.209 \pm 0.033 \mathrm{mg} \mathrm{L}^{-1}$ between $\mathrm{W}_{0}$ and $\mathrm{W}_{1}$. The levels of TAN were further reduced from $0.209 \pm 0.033$ at $\mathrm{W}_{1}$ to $0.023 \pm 0.003$ and $0.049 \pm 0.013 \mathrm{mg} \mathrm{L}^{-1}$ at $\mathrm{W}_{2}$ and $\mathrm{W}_{3}$, respectively. It is possible that the reduction in TAN is due to oxidization to nitrite by ammonia oxidizing bacteria. In this study, decreasing concentrations of ammonia were observed between days $30\left(\mathrm{~W}_{1}\right)$ and $90\left(\mathrm{~W}_{3}\right)$, which contrasts with the gradually increasing concentrations of nitrate observed during this same period. By the end of the growing period $\left(\mathrm{W}_{3}\right)$, the level of nitrate had reached its highest concentration of $3.977 \pm 0.061 \mathrm{mg} \mathrm{L}^{-1}$, while nitrite was not detected during the course of this study. The high levels of nitrate and low levels of ammonia and nitrite suggest that the nitrification process was established in the shrimp pond (Moreno-Garrido, 2008). Nitrification takes place in two sequential steps: the first step is the conversion of ammonium into nitrite, and the second step is the conversion of nitrite into nitrate (Eding, Kamstra, Verreth, Huisman, \& Klapwijk, 2006). In addition, the concentration of chlorophyll $a$ increased over the course of the shrimp growing period. The highest concentration of chlorophyll $a, 187.16 \mu \mathrm{g} \mathrm{\textrm {L } ^ { - 1 }}$, was observed during 
the final sample period $\left(\mathrm{W}_{3}\right)$; this period has the highest nitrate concentration, indicating the presence of an increasing phytoplankton mass due to accumulation of nitrate in the pond, which stimulates their growth by nitrate utilization (Dortch, 1990).

\subsection{Microbial community composition in the shrimp cultivation pond}

In the shrimp culture pond, the major source of nitrogen waste come from protein in artificial feed pellets. In fact, only $20-30 \%$ of the nitrogen found in feed is converted into shrimp biomass (Kutako, Powtongsook, \& Menasveta, 2009), while the rest is accumulated in high organic-content sediment at the bottom of the pond (Kutako, et al., 2009). In nature, ammonia is subsequently converted into nitrite and nitrate by the nitrification process, and the nitrate is thereafter eliminated from the pond by the denitrification process in the sediment. The nitrification and denitrification processes are linked with specific groups of bacteria naturally found in ponds. Generally, $\beta$ - and $\gamma$-proteobacteria are found in a higher percentage of bacterial communities from polluted waters (Rubin \& Leff, 2007), whereas cyanobacteria are used as feed for increasing the growth rate and size of shrimp (Focken, Groth, Coloso, \& Becker, 1998) or for nutrient removal in aquaculture systems (Chaowanapreecha, Wantawin, \& Ruengjitchatchawalya, 2007). In this study, a DGGE profile of the microbial community over the course of a single shrimp growing period of 3 months is shown (Fig. 1). The majority of the 14 bacteria found (Table 2) were identified as $\beta$-proteobacteria ( 8 out of 14 or $57.14 \%$ ), which consists of several different groups of bacteria involved in degradation, nitrogen fixation and ammonia oxidation (Rubin \& Leff, 2007). These bacteria included Nitrosomonas, Flavobacterium, Exiguobacterium, Burkholderia and Nitrosospira. The remaining bacteria identified in this study belonged to the following groups: $\alpha$-proteobacteria ( 1 out of 14 or $7.14 \%$ ), $\gamma$-proteobacteria ( 2 out of 14 or $14.28 \%$ ), cyanobacteria ( 2 out of 14 or $14.28 \%$ ) and Cytophaga-Flavobacterium-Bacteroides (CFB; 1 out of 14 or 7.14\%). Changes in the microbial community's composition occurred over time as demonstrated by changes in the dominant bands observed from the DGGE profile and the affiliated sequences retrieved following DNA extraction. The observed microbial community in the water before the addition of shrimp $\left(\mathrm{W}_{0}\right)$ consisted of 8 bands (Fig. 1). Five of these bands (a1, a3, a5, a7 and a12) were identified as members of the $\beta$-proteobacteria group, which represented the majority of bacteria identified in this study. Band al was identified as a member of Nitrosomonas sp. This nitrifying bacterium is microflora, found in shrimp grow-out ponds (Ghosh, Sasmal, \& Abraham), that remove ammonia from the water; it is also found in various other environments (Kowalchuk \& Stephen, 2001). Ammonia oxidizing bacteria are classified into 5 genera: Nitrosomonas, Nitrosovibrio, Nitrosococcus, Nitrsolobus and Nitrospira, while nitrite oxidizing bacteria are classified into three genera: Nitrobacter, Nitrococcus and Nitrospira (Altschul, et al.). Nitrosomonas and Nitrobacter are commonly used commercially in aquaculture as bioremediators (Altschul, et al.). Band a3 was closely related to Flavobacterium, which is a cellulose digesting bacterium involved in shrimp shell degradation (W. C. Chen, Tseng, Hsieh, Wang, \& Wang). Bands a5, a7 and a12 were identified as Exiguobacterium spp. These bacteria have been found in a variety of environments (Vishnivetskaya, Kathariou, \& Tiedje, 2009), including alkaline (Gopalsamy, Mody, Datta, \& Jha, 2008), low temperature (Ponder, Thomashow, \& Tiedje, 2008), or in aquaculture systems (Lopez-Cortes, Schumann, Pukall, \& Stackebrandt, 2006). In an aquaculture system, these bacteria have the potential to improve the survival rate and development of Artemia sp. (Fardeau, Combet-blanc, \& Ollivier, 2008), which is used as feed in shrimp nurseries. Moreover, these bacteria, much like Bacillus sp. (Kim, et al., 2005), can produce polypeptide antibiotics, such as bacitracin, gramicidin S, polymyxin, and tyrotricidin, which are active against a wide range of bacteria (Drablos, Nicholson, \& Ronning, 1999; Morikawa, Ito, \& Imanaka, 1992; Perez, Suarez, \& Castro, 1993) that might be harmful to shrimp. Two of the bands (a6 and a11) were identified as members of cyanobacteria. The presence of cyanobacteria was already suggested by the increase in chlorophyll $a$ content in the shrimp water that was observed during the shrimp growing period. Increased levels of chlorphyll $a$, as shown in Table 1, were due to the growth of phytoplankton from nitrogen uptake or nitrogen-fixing in the shrimp pond (Sprober, Shafik, Prosing, Kovocs, \& Herodek, 2003). Additionally, one band, a9, was closely related to Pseudomonas sp., a member of $\gamma$-proteobacteria. Based on traditional culturing studies, the Pseudomonadaceae family of bacteria is usually considered to be a predominant bacterial population in mariculture environments (Deng, et al., 2009).

Based on the DGGE profile, the microbial community at the end of the first month of cultivation $\left(\mathrm{W}_{1}\right)$ consisted of 8 bands (Fig. 1). Six of the bands (b1, b3, b4, b5, b7 and b12) were identified as members of the $\beta$-proteobacteria group, which is the most prevalent group in this study. Of these, the 4 bands (b1, b3, b5, and b7) had the same identity as the a1, a3, a5, and a7 bands, respectively, from the sample taken at $\mathrm{W}_{0}$. The remaining three bands, namely, b4, b9 and b12, represent new members detected in the $\mathrm{W}_{1}$ sample. Band $\mathrm{b} 9$ was identified as Nitrobacter winogradskyi, a member of the $\alpha$-proteobacteria group. These nitrite-oxidizing bacteria can oxidize nitrite to nitrate (Teske, et al., 1994) as suggested by the observed increase in nitrate concentration 
between $\mathrm{W}_{0}$ and $\mathrm{W}_{1}$. Band b12 was closely related to Burkholderia, which has been used for such agricultural purposes as biodegradation, including microcystin degradation (Kemes, et al., 2008), biocontrol (Parke \& Gurian-Sherman, 2001) and serving as a plant-growth-promoting rhizobacteria (Compant, et al., 2005). However, bands a9, a11 and a12, which were present at $\mathrm{W}_{0}$, had faded out by the time the $\mathrm{W}_{1}$ sample was taken.

The microbial community at the end of the second month $\left(\mathrm{W}_{2}\right)$ consisted of 8 bands. Six of them (c1, c3, c4, c5, $\mathrm{c} 8$, and c13), i.e., the majority of the bands, were identified as members of the $\beta$-proteobacteria group. These 6 bands were similar, respectively, to bands $\mathrm{b} 1, \mathrm{~b} 3, \mathrm{~b} 4, \mathrm{~b} 5, \mathrm{~b} 7$ and $\mathrm{b} 12$ from the $\mathrm{W}_{1}$ time point. Band c6 was identified as the same member of the cyanobacteria as band b6 in $\mathrm{W}_{1}$. Band c10, identified as Nitrobacter winogradskyi, shared the same identity as band b9.

The microbial community at the end of the third month $\left(\mathrm{W}_{3}\right)$ consisted of 9 bands. Five of them were identified as members of the $\beta$-proteobacteria: $\mathrm{d} 1$ (or a1, b1, c1), d3 (or a5, b5, c5), d4 (or a7, b7, c8), d10 and d11 (or a12). Band $\mathrm{d} 1, \mathrm{~d} 3$ and $\mathrm{d} 4$ were previously found in all the other cultivation periods, while a new band, $\mathrm{d} 10$, was identified as Nitrosospira sp. This bacterium is a low-salinity nitrifying bacterium (Bernhard, Donn, Giblin, \& Stahl, 2005). During the course of this study, the salinity was gradually decreased from 10 to 2 psu to prevent shrimp disease (Limsuwan, et al., 2002). Band d11, in $\mathrm{W}_{3}$, had a similar sequence to that of band a12 in $\mathrm{W}_{0}$, suggesting the reappearance of this bacterium. The $\beta$-proteobacteria represented by bands $\mathrm{c} 3$ and $\mathrm{c} 4$, which were found in $\mathrm{W}_{2}$, were not detected in $\mathrm{W}_{3}$. Band $\mathrm{c} 3$ (or a3, b3), which was identified as closely related to the shrimp shell-degrading bacterium Flavobacterium (H. C. Chen \& Hsu, 1997) was not found in $\mathrm{W}_{3}$. Band d12 was closely related to Aquiflexum balticum, a member of the Cytophaga-Flavobacterium-Bacteroides (CFB) group of bacteria, which is considered to be important for the degradation of complex polysaccharides in aquatic environments (Brettar, Christen, \& Hofle, 2004); these polysaccharides have also been found in shrimp shells (Mathur \& Narang, 1990). A role in polysaccharide degradation might explain the observation that the shrimp shell degradation bacterium Flavobacterium is replaced by Aquiflexum balticum during the course of this study. Moreover, Aquiflexum balticum thrives at the optimum salinity and temperature of $1.5 \mathrm{psu}$ and $30{ }^{\circ} \mathrm{C}$, respectively, which was similar to the conditions in the shrimp pond at the time the $\mathrm{W}_{3}$ sample was taken (Brettar, et al., 2004). Band d6 (or b9, c10) was a $\alpha$-proteobacteria that is closely related to Nitrobacter winogradskyi, which was also found in $\mathrm{W}_{1}$ and $\mathrm{W}_{2}$. Therefore, nitrite concentrations, as shown in Table 1 , were stabilized by this bacterium. Additional members of the $\gamma$-proteobacteria (d8) and Cytophaga-Flavobacterium-Bacteroides (d12) groups were first detected in $\mathrm{W}_{3}$. Band d8 was closely related to Stenotrophomonas maltophilia, which has the potential to degrade proteins (Garcia, et al., 2002) and might be the nitrogen source of ammonia-oxidizing bacteria for the production of ammonium (Broderick, 1978).

Overall, there were 3 groups of microbial dynamics observed in this study. The first dynamic consisted of the microbes that were found at all the time points investigated: Nitrosomonas eutropha, Exiguobacterium SKRP 5, and Exiguobacteria sp. CNJ771. The ammonia oxidizing bacteria, Nitrosomonas eutropha, has been reported as typical of the flora in earthen shrimp ponds, due to the excess ammonia that is found in these ponds. The sources of excess ammonia had been from overfeeding, shrimp feces or the sediment for nitrite production (Lied \& Braaten, 1984). Moreover, this bacterium also correlated with Nitrobacter winogradskyi, a nitrite oxidizing bacteria which can oxidize nitrite to nitrate (Lees \& Simpson, 1957) that was keeping nitrite concentrations at less than $0.05 \mathrm{mg} / \mathrm{l}$, while nitrate concentrations increased over the growth period. The other ammonia-oxidizing bacteria, Nitrosospira sp., which was only found in $\mathrm{W}_{3}$ sample, might be working with Nitrosomonas eutropha to control the ammonia concentration in the shrimp pond system. Exiguobacterium spp., another type of microflora found in aquacultures, was also found in Artemia cysts (C. s. Orozco-Medina, Maeda-Martı'nez, \& Lo'pez-Corte's, 2002) and gut rumen (C. Orozco-Medina, Lopez-Cortes, \& Maeda-Martinez, 2009), salmon intestinal systems (Ring, Sperstad, Kraugerud, \& Krogdahl, 2008) and shrimp farming sediment (Boonapatcharoen, Techkarnjanaruk, Wanichpongpan, \& Ruenglertpanyakul, 2551). Therefore, it was expected that Exiguobacterium spp. would also be found during this investigation. Moreover, Exiguobacterium undae (found in $\mathrm{W}_{2}$ and $\mathrm{W}_{3}$ ) and Exiguobacterium sp. (found in $\mathrm{W}_{0}$ and $\mathrm{W}_{4}$ ) were also associated with the activity of Exiguobacterium SKRP 5 and Exiguobacteria sp. CNJ771 during the shrimp growing period. The second group of microbial dynamics involved the replacement of Flavobacteriales bacterium with Aquiflexum balticum, both of which are bacteria involved in shrimp shell degradation. In the first two months $\left(\mathrm{W}_{0}\right.$ to $\left.\mathrm{W}_{2}\right)$, Flavobacteriales bacterium was responsible for the degradation of shrimp shells. However, as the salinity gradually decreased to 2 psu (to control pathogens in the shrimp pond) and the temperature rose to $28.6{ }^{\circ} \mathrm{C}$, the environmental conditions became optimal for Aquiflexum balticum; this finding might account for the observed replacement of Flavobacteriales bacterium with Aquiflexum balticum. The third group of microbial dynamics involved bacteria that were observed only at one time point, such as Synechococcus sp. Y0011 ( $\left.\mathrm{W}_{0}\right)$, Stenotrophomonas 
maltophilia $\left(\mathrm{W}_{3}\right)$, or at several time points, such as Pseudomonas lanceolata $\left(\mathrm{W}_{0}\right.$ and $\left.\mathrm{W}_{3}\right)$ and Burkholderia sp. WBF2 $\left(\mathrm{W}_{1}\right.$ and $\left.\mathrm{W}_{2}\right)$. As previously mentioned, although this third group of bacteria was not found at all of the time points investigated, they have an important role in balancing the shrimp culturing system, which is needed for a successful shrimp cultivation.

\section{Conclusions}

The importance of the microbial community composition for water quality and shrimp production suggests the need for management strategies that promote beneficial processes, while controlling adverse processes. The interrelationships between various functional groups within the microbial community are not completely understood, and relationships between microbes, system inputs, water quality, and shrimp health are complex. In this study, we investigated changes in water quality and microbial community composition and dynamics in shrimp farming water over the course of a single shrimp growing period. Moreover, we studied their correlations with one another. Overall, the microbial community during the shrimp growing period consisted of 14 species, including $\alpha$-proteobacteria ( 1 out of 14$), \beta$-proteobacteria ( 8 out of 14 ), $\gamma$-proteobacteria ( 2 out of 14), Cyanobacteria ( 2 out of 14), and CFB (1 out of 14). These species were grouped into 3 different types of microbial dynamics. The first group dynamic consisted of microbes that were found in all samples, which included Nitrosomonas eutropha, Exiguobacterium SKRP 5, and Exiguobacteria sp. CNJ771. The second group dynamic involved the replacement of Flavobacteriales bacterium with Aquiflexum balticum, both of which are associated with shrimp shell degradation. The third group dynamic involved bacteria that were observed only once, such as Synechococcus sp. Y0011 ( $\left.\mathrm{W}_{0}\right)$ and Stenotrophomonas maltophilia $\left(\mathrm{W}_{2}\right)$, or several times, such as Pseudomonas lanceolata $\left(\mathrm{W}_{0}\right.$ and $\left.\mathrm{W}_{3}\right)$ and Burkholderia sp. WBF2 $\left(\mathrm{W}_{1}\right.$ and $\left.\mathrm{W}_{2}\right)$. Changes in the composition of the microbial community were significantly linked to temperature, salinity and nutrient (ammonia, nitrite and nitrate) concentrations. Future studies aimed at understanding the role of each micro-organism within the shrimp pond community will provide greater guidance not only for the development of more successful shrimp culturing systems but also for the application of these developments for sustainable environmental protections.

\section{References}

Altschul, S. F., Madden, T. L., Schaffer, A. A., Zhang, J., Zhang, Z., Miller, W., et al. (1997). Gapped BLAST and PSI-BLAST: a new generation of protein database programs. Nucleic Acids Research, 25, 3389-3402.

Amann, R. I., Ludwig, W., \& Schleifer, K. H. (1995). Phylogenetic identification and in situ detection of individual microbial cells without cultivation. Microbiology and Molecular Biology Reviews, 59(1), 143.

Bernhard, A. E., Donn, T., Giblin, A. E., \& Stahl, D. A. (2005). Loss of diversity of ammonia oxidizing bacteria correlates with increasing salinity in an estuary system. Environmental Microbiology, 7(9), 1289-1297. http://dx.doi.org/10.1111/j.1462-2920.2005.00808.x

Boonapatcharoen, N., Techkarnjanaruk, S., Wanichpongpan, P., \& Ruenglertpanyakul, W. (2551). Effect of Natural Sunlight on Microbial Population in Shrimp Farming Sediment. KMUTT Research and Development Journal, 31(3), 451-462.

Brettar, I., Christen, R., \& Hofle, M. G. (2004). Aquiflexum balticum gen. nov., sp. nov., a novel marine bacterium of the Cytophaga-Flavobacterium-Bacteroides group isolated from surface water of the central Baltic Sea. International journal of systematic and evolutionary microbiology, 54(6), 2335-2341. http://dx.doi.org/10.1099/ijs.0.63255-0

Broderick, G. A. (1978). In vitro procedures for estimating rates of ruminal protein degradation and proportions of protein escaping the rumen undegraded. The Journal of Nutrition, 108(2), 181.

Chaowanapreecha, K., Wantawin, C., \& Ruengjitchatchawalya, M. (2007). Optimum Storage Condition for Spirulina Mat before Applying to Ammonia-Nitrogen Removal from Simulated Shrimp Culturing Water. Kasetsart journal: Natural sciences, 41(1-2), 136.

Chen, H. C., \& Hsu, C. C. (1997). Production of chitin and its partial deacetylation from shrimp shells by microbial degradation. Journal of the Chinese Agricultural Chemical Society, 35(3), 342-353.

Chen, W. C., Tseng, W. N., Hsieh, J. L., Wang, Y. S., \& Wang, S. L. (2010). Biodegradation and microbial community changes upon shrimp shell wastes amended in mangrove river sediment. Journal of Environmental Science and Health, Part B, 45(5), 473-477. http://dx.doi.org/10.1080/03601231003800305

Compant, S., Reiter, B., Sessitsch, A., Nowak, J., Clement, C., \& Ait Barka, E. (2005). Endophytic colonization of Vitis vinifera L. by plant growth-promoting bacterium Burkholderia sp. strain PsJN. Applied and environmental microbiology, 71(4), 1685-1693. http://dx.doi.org/10.1128/AEM.71.4.1685-1693.2005 
Cook, H. L., \& Murphy, M. A. (1969). The culture of larval penaeid shrimp. Transactions of the American Fisheries Society, 98(4), 751-754. http://dx.doi.org/10.1577/1548-8659(1969)98[751:TCOLPS]2.0.CO;2

Dar, S. A., Kuenen, J. G., \& Muyzer, G. (2005). Nested PCR-denaturing gradient gel electrophoresis approach to determine the diversity of sulfate-reducing bacteria in complex microbial communities. Applied and environmental microbiology, 71(5), 2325-2330. http://dx.doi.org/10.1128/AEM.71.5.2325-2330.2005

Deng, H., He, C., Zhou, Z., Liu, C., Tan, K., Wang, N., et al. (2009). Isolation and pathogenicity of pathogens from skin ulceration disease and viscera ejection syndrome of the sea cucumber Apostichopus japonicus. Aquaculture, 287(1-2), 18-27. http://dx.doi.org/10.1016/j.aquaculture.2008.10.015

Devereux, R., Kane, M. D., Winfrey, J., \& Stahl, D. A. (1992). Genus-and group-specific hybridization probes for determinative and environmental studies of sulfate reducing bacteria. Systematic and Applied Microbiology, 15, 601-609.

Dortch, Q. (1990). The interaction between ammonium and nitrate uptake in phytoplankton. Marine ecology progress series. Oldendorf, 61(1), 183-201.

Drablos, F., Nicholson, D., \& Ronning, M. (1999). EXAFS study of zinc coordination in Bacitracin A. Biochimica et Biophysica Acta, 1431, 433-442.

Eding, E. H., Kamstra, A., Verreth, J. A. J., Huisman, E. A., \& Klapwijk, A. (2006). Design and operation of nitrifying trickling filters in recirculating aquaculture: A review. Aquacultural Engineering, 34, 234-260.

Fardeau, M., Combet-blanc, Y., \& Ollivier, B. (2008). Bacterial Strains of Genus Exiguobacterium, Culture Method and Uses: EP Patent 1,570,050.

Focken, U., Groth, A., Coloso, R. M., \& Becker, K. (1998). Contribution of natural food and supplemental feed to the gut content of Penaeus monodon Fabricius in a semi-intensive pond system in the Philippines. Aquaculture, 164(1-4), 105-116. http://dx.doi.org/10.1016/S0044-8486(98)00180-X

Garcia, D. O., Timenetsky, J., Martinez, M. B., Francisco, W., Sinto, S. I., \& Yanaguita, R. M. (2002). Proteases (caseinase and elastase), hemolysins, adhesion and susceptibility to antimicrobials of Stenotrophomonas maltophilia isolates obtained from clinical specimens. Brazilian Journal of Microbiology, 33(2), 157-162. http://dx.doi.org/10.1590/S1517-83822002000200012

Ghosh, S., Sasmal, D., \& Abraham, T. J. Microcosm evaluation of indigenous microflora of traditional shrimp farming system as bioremediators. Indian Journal of Fisheries, 57(1), 97-101.

Gopalsamy, G., Mody, K. H., Datta, S., \& Jha, B. (2008). Solid nutrient media useful for isolating and identifying alkaliphilic bacteria: US Patent App. 20,090/176,268.

Kemes, G., Krsanach, R., Pinto, L. S., Dellagostin, O. A., Yunes, J. S., \& Matthiensen, A. (2008). Biodegradation of microcystins by aquatic Burkholderia sp. from a South Brazilian coastal lagoon. Ecotoxicology and Environmental Safety, 69, 358-365.

Kesarcodi-Watson, A., Kaspar, H., Lategan, M. J., \& Gibson, L. (2008). Probiotics in aquaculture: The need, principles and mechanisms of action and screening processes. Aquaculture, 274, 1-14. http://dx.doi.org/10.1016/j.aquaculture.2007.11.019

Kim, I. G., Lee, M. H., Jung, S. Y., Song, J. J., Oh, T. K., \& Yoon, J. H. (2005). Exiguobacterium aestuarii sp. nov. and Exiguobacterium marinum sp. nov., isolated from a tidal flat of the Yellow Sea in Korea. International journal of systematic and evolutionary microbiology, 55(2), 885. http://dx.doi.org/10.1099/ijs.0.63308-0

Kongkeo, H., \& Davy, F. B. (2011). Backyard hatcheries and small scale shrimp and prawn farming in Thailand. Success Stories in Asian Aquaculture, 67-83.

Kowalchuk, G. A., \& Stephen, J. R. (2001). Ammonia-oxidizing bacteria: a model for molecular microbial ecology. Annual Reviews in Microbiology, 55(1), 485-529. http://dx.doi.org/10.1146/annurev.micro.55.1.485

Kutako, M., Powtongsook, S., \& Menasveta, P. (2009). Effect of illumination in nitrogen conversion and microorganism diversity in sediment from shrimp pond. Phycologia, 48(4).

Lees, H., \& Simpson, J. R. (1957). The biochemistry of the nitrifying organisms. 5. Nitrite oxidation by Nitrobacter. Biochemical Journal, 65(2), 297.

Lied, E., \& Braaten, B. (1984). The effect of feeding and starving, and different ratios of protein energy to total energy in the feed on the excretion of ammonia in Atlantic cod (Gadus morhua). Comparative Biochemistry and Physiology Part A: Physiology, 78(1), 49-52. http://dx.doi.org/10.1016/0300-9629(84)90090-2 
Limsuwan, C., Somsiri, T., \& Silarudee, S. (2002). The appropriate salinity level of brine water for raising black tiger prawn under low-salinity conditions. Aquatic Animal Health Research Institute Newsletter, Department of Fisheries, Bangkok, Thailand, 1, 2-4.

Lopez-Cortes, A., Schumann, P., Pukall, R., \& Stackebrandt, E. (2006). Exiguobacterium mexicanum sp. nov. and Exiguobacterium artemiae sp. nov., isolated from the brine shrimp Artemia franciscana. Systematic and applied microbiology, 29(3), 183-190. http://dx.doi.org/10.1016/j.syapm.2005.09.007

Mathur, N. K., \& Narang, C. K. (1990). Chitin and chitosan, versatile polysaccharides from marine animals. Journal of Chemical Education, 67(11), 938. http://dx.doi.org/10.1021/ed067p938

Moreno-Garrido, I. (2008). Microalgae immobilization: Current techniques and uses. Bioresource Technology, 99(10), 3949-3964. http://dx.doi.org/10.1016/j.biortech.2007.05.040

Moriarty, D. J. W. (1999). Disease control in shrimp aquaculture with probiotic bacteria. Paper presented at the The 8th International Symposium on Microbial Ecology, Atlantic Canada Society for Microbial Ecology, Halifax, Canada.

Morikawa, M., Ito, M., \& Imanaka, T. (1992). Isolation of a new surfactin producer Bacillus pumilus A-1, and cloning and nucleotide sequence of the regulator gene, psf-1. Journal of Fermentation and Bioengineering, 74, 255-261.

Orozco-Medina, C., Lopez-Cortes, A., \& Maeda-Martinez, A. M. (2009). Aerobic Gram-positive heterotrophic bacteria Exiguobacterium mexicanum and Microbacterium $s p$. in the gut lumen of Artemia franciscana larvae under gnotobiotic conditions. Current Science, 96(1), 120-129.

Orozco-Medina, C. s., Maeda-Martı'nez, A. M., \& Lo'pez-Corte's, A. (2002). Effect of aerobic Gram-positive heterotrophic bacteria associated with Artemia franciscana cysts on the survival and development of its larvae. Aquaculture, 213, 15-29.

Parke, J. L., \& Gurian-Sherman, D. (2001). Diversity of the Burkholderia cepacia complex and implications for risk assessment of biological control strains. Annual review of phytopathology, 39(1), 225-258. http://dx.doi.org/10.1146/annurev.phyto.39.1.225

Perez, C., Suarez, C., \& Castro, G. R. (1993). Antimicrobial activity determined in strains of Bacillus circulans cluster. Folia Microbiologica, 38, 25-28.

Ponder, M. A., Thomashow, M. F., \& Tiedje, J. M. (2008). Metabolic activity of Siberian permafrost isolates, Psychrobacter arcticus and Exiguobacterium sibiricum, at low water activities. Extremophiles, 12(4), 481-490. http://dx.doi.org/10.1007/s00792-008-0151-0

Pouliotte, J., Islam, N., Smit, B., \& Islam, S. (2006). Livelihoods in rural Bangladesh. Tiempo, 59, 18-22.

Ring, E., Sperstad, S., Kraugerud, O. F., \& Krogdahl. (2008). Use of 16S rRNA gene sequencing analysis to characterize culturable intestinal bacteria in Atlantic salmon (Salmo salar) fed diets with cellulose or non starch polysaccharides from soy. Aquaculture Research, 39(10), 1087-1100, Rubin, M. A., \& Leff, L. G. (2007). Nutrients and other abiotic factors affecting bacterial communities in an Ohio River (USA). Microbial ecology, 54(2), 374-383.

Sambrook, J., Fritsch, E. F., \& Maniatis, T. (1989). Molecular Cloning - A Laboratory Manual (2 ${ }^{\text {nd }}$ ed.). New York: Cold Spring Habour Laboratory Press.

Sandifer, P. A., \& Hopkins, J. S. (1996). Conceptual design of a sustainable pond-based shrimp culture system. Aquacultural Engineering, 15, 41-52.

Sprober, P., Shafik, H. M., Prosing, M., Kovocs, A. W., \& Herodek, S. (2003). Nitrogen uptake and fixation in the cyanobacterium Cylindrospermopsis raciborskii under different nitrogen conditions. Hydrobiologia, 506(1), 169-174. http://dx.doi.org/10.1023/B:HYDR.0000008617.90245.5f

Strickland, J. D. H., \& Parsons, T. R. (1972). A practical handbook of sea-water analysis (2 ${ }^{\text {nd }}$ Edition ed.): Fisheries Research Board of Canada Bulletin.

Teske, A., Alm, E., Regan, J. M., Toze, S., Rittmann, B. E., \& Stahl, D. A. (1994). Evolutionary relationships among ammonia-and nitrite-oxidizing bacteria. Journal of bacteriology, 176(21), 6623.

Vishnivetskaya, T. A., Kathariou, S., \& Tiedje, J. M. (2009). The Exiguobacterium genus: biodiversity and biogeography. Extremophiles, 13(3), 541-555. 
Watts, J. E. M., Wu, Q., Schreier, S. B., May, H. D., \& Sowers, K. R. (2001). Comparative analyses of PCB dechlorinating communities in enrichment cultures using three different molecular screening techniques. Environmental Microbiology, 3, 710- 719.

Zhou, J., Bruns, M. A., \& Tiedje, J. M. (1996). DNA recovery from soils of diverse composition. Applied and environmental microbiology, 62(2), 316.

Table 1. Physical and chemical properties of water column samples obtained during the shrimp growing period

\begin{tabular}{|c|c|c|c|c|}
\hline \multirow{2}{*}{ Parameter } & \multicolumn{4}{|c|}{ Water samples } \\
\hline & $\mathrm{W}_{0}$ & $\mathrm{~W}_{1}$ & $\mathrm{~W}_{2}$ & $\mathrm{~W}_{3}$ \\
\hline $\begin{array}{l}\text { Physical property } \\
-\mathrm{pH} \\
\text {-Temperature }\left({ }^{\circ} \mathrm{C}\right) \\
\text {-Salinity (PSU) } \\
\end{array}$ & $\begin{array}{c}7.8+0.03 \\
22.4 \pm 0.3 \\
10\end{array}$ & $\begin{array}{c}7.9 \pm 0.08 \\
18.2 \pm 0.5 \\
7\end{array}$ & $\begin{array}{c}8.0 \pm 0.07 \\
27.3 \pm 0.6 \\
5\end{array}$ & $\begin{array}{c}7.8 \pm 0.1 \\
28.6 \pm 0.2 \\
\frac{2}{2}\end{array}$ \\
\hline $\begin{array}{c}\text { Chemical property } \\
\text { - Chlorphyll } a\left(\mu \mathrm{g} \mathrm{L}^{-1}\right) \\
\text { - Total Ammonia Nitrogen }\left(\mathrm{mg} \mathrm{L}^{-1}\right) \\
\text {-Nitrite nitrogen }\left(\mathrm{mg} \mathrm{L}^{-1}\right) \\
\text {-Nitrate nitrogen }\left(\mathrm{mg} \mathrm{L}^{-1}\right)\end{array}$ & $\begin{array}{l}42.67 \pm 5.2 \\
0.262 \pm 0.014 \\
\quad<0.05 \\
2.723 \pm 0.059\end{array}$ & $\begin{array}{l}71.00 \pm 4.3 \\
0.209 \pm 0.033 \\
\quad<0.05 \\
3.165 \pm 0.009\end{array}$ & $\begin{array}{l}164.63 \pm 11.4 \\
0.023 \pm 0.003 \\
\quad<0.05 \\
3.605 \pm 0.070\end{array}$ & $\begin{array}{l}187.16 \pm 15.1 \\
0.049 \pm 0.013 \\
\quad<0.05 \\
3.977 \pm 0.061\end{array}$ \\
\hline
\end{tabular}

(90-day) (Means $\pm \mathrm{SD}, \mathrm{N}=3$ )

Table 2 . The $16 \mathrm{~S}$ rRNA gene sequences of the microbial community in shrimp pond water with high similarity by Blast searches

\begin{tabular}{ccccc}
\hline Band & Bacteria & $\begin{array}{c}\% \\
\text { Identity }\end{array}$ & Group & $\begin{array}{c}\text { Accession } \\
\text { Number }\end{array}$ \\
\hline a1, b1, c1, d1 & Nitrosomonas eutropha & 99 & $\beta$-proteobacteria & HQ433572 \\
a3, b3, c3 & Uncultured Flavobacteriales bacterium & 84 & $\beta$-proteobacteria & HQ433562 \\
clone LiUU-11-73 & & & $\beta$-proteobacteria \\
a5, b5, c5, d3 & Exiguobacterium SKRP 5 & 99 & HQ433563 \\
a6, b6, c6 & Synechococcus sp. RS9915 & 99 & Chlobacteria and & \\
& & & $\beta$-proteobacteria & HQ433564 \\
a7, b7, c8, d4 & Exiguobacteria sp. CNJ771 & 99 & $\gamma$-proteobacteria & HQ4335567 \\
a 9, d5 & Pseudomonas lanceolata & 99 & Cyanobacteria and & \\
a11 & Synechococcus sp. Y0011 & 92 & Chloroplast & HQ433561 \\
& & 97 & $\beta$-proteobacteria & HQ433569 \\
a12, d11 & Exiguobacterium sp. & 98 & $\beta$-proteobacteria & HQ433557 \\
b4, c4 & Exiguobacterium undae & 99 & $\alpha$-proteobacteria & HQ433573 \\
b9, c10, d6 & Nitrobacter winogradskyi & 99 & $\beta$-proteobacteria & HQ433556 \\
b12, c13 & Burkholderia sp. WBF2 & $\gamma$-proteobacteria & HQ433555 \\
d8 & Stenotrophomonas maltophilia & 99 & $\beta$-proteobacteria & HQ433552 \\
d10 & Nitrosospira sp. & 93 & Cytophaga-Flavobacter & \\
d12 & Aquiflexum balticum & 92 & ium-Bacteroides & HQ433566 \\
\hline
\end{tabular}

Remark: $\mathrm{a}=$ microbial community in $\mathrm{W}_{0}$ (water samples taken before shrimp were released into the earthen pond)

$\mathrm{b}, \mathrm{c}$ and $\mathrm{d}=$ microbial community in $\mathrm{W}_{1}, \mathrm{~W}_{2}$ and $\mathrm{W}_{3}$ (water samples taken one, two and three months after shrimp were released, respectively) 


\section{$w_{1} w_{1} w_{2} w_{3}$}

(a) (b) (c) (d)

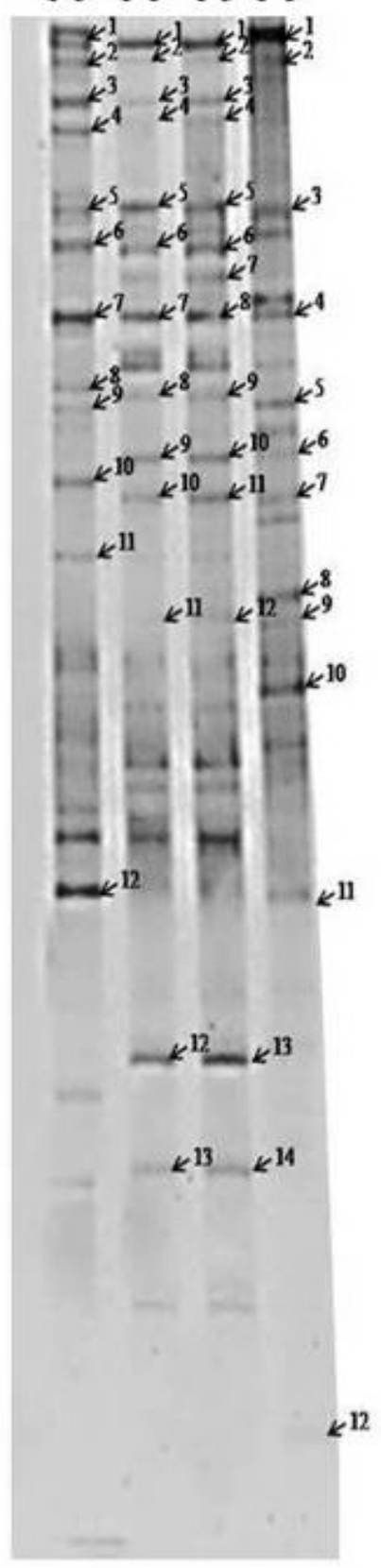

Figure 1. DGGE profile of bacterial amplicons amplified from the water: $\mathrm{W}_{0}$ (Lane a), microbial community before the release of shrimp into the earthen pond; $\mathrm{W}_{1}$ (Lane b), $\mathrm{W}_{2}$ (Lane $\mathrm{c}$ ) and $\mathrm{W}_{3}$ (Lane d), depict the microbial community at time points 1,2 and 3 months, respectively, during the shrimp growing period 